\title{
Thermochemical and Theoretical Study of Some Quinoxaline 1,4-Dioxides and of Pyrazine 1,4-Dioxide
}

W. E. Acree, J r., ${ }^{*, \dagger}$ J oyce R. Powell, ${ }^{\dagger}$ Sheryl A. Tucker, ${ }^{\dagger}$ Maria D. M. C. Ribeiro da Silva, ${ }^{\ddagger}$ M. Agostinha R. Matos, ${ }^{\ddagger}$ J . M. Gonçalves, ${ }^{\ddagger}$ L. M. N. B. F. Santos, ${ }^{\ddagger}$ V. M. F. Morais, ${ }^{\S}$ and G. Pilcher"

Department of Chemistry, University of North Texas, Denton, Texas, 76203-0068, Departamento de Química, Faculdade de Ciências, Universidade do Porto, P-4150, Porto, Portugal, Instituto de Ciências Biomédicas Abel Salazar, Universidade do Porto, P-4050 Porto, Portugal, and Department of Chemistry, University of Manchester, Manchester M13 9PL, U.K.

Received November 18, $1996^{\otimes}$

The following standard molar enthalpies of formation in the gaseous state at $298.15 \mathrm{~K}$ were determined from the enthalpies of combustion of the crystalline solids, and their enthalpies of sublimation and the mean $(\mathrm{N}-\mathrm{O})$ bond dissociation enthal pies were derived. $\Delta_{\mathrm{f}} \mathrm{H}_{\mathrm{m}}^{0}(\mathrm{~g}) ;\langle\mathrm{D}(\mathrm{N}-\mathrm{O})\rangle$ $\left(\mathrm{kJ} \mathrm{mol}{ }^{-1}\right.$ ): quinoxaline 1,4-dioxide, $227.1 \pm 2.4 ; 255.8 \pm 2.0 ; 2$-methylquinoxal ine 1,4-dioxide, 169.9 $\pm 7.2 ; 268.3 \pm 4.9 ; 2$-methyl-3-acetylquinoxaline 1,4-dioxide, $33.1 \pm 5.0 ; 251.6 \pm 4.2 ; 2$-phenyl-3benzoylquinoxaline 1,4-dioxide, 355.2 \pm 7.1; $227.3 \pm 5.4$; 2-methyl-3-carbomethoxyquinoxaline 1,4dioxide, $-148.7 \pm 3.2 ; 242.3 \pm 3.9$; pyrazine 1,4-dioxide, $186.5 \pm 1.9 ; 254.0 \pm 2.3 ;$ 2-methyl-5pyrazinecarboxylic acid, $-213.6 \pm 1.7$. Unconstrained geometry optimizations by ab initio cal culations showed the effect of steric hindrance on changes in extended delocalizations and were in accord with the trends in the mean bond dissociation enthalpies.

\section{Introduction}

A reaction scheme has been employed by $\mathrm{Holm}$ and his colleagues, ${ }^{1,2}$ to order various oxygenated species, including $\mathrm{N}$-oxides, in terms of their abilities to transfer oxygen atoms in molybdenum(IV) to molybdenum(VI) conversions, by considering the enthalpy of the reaction

$$
\mathrm{RN}(\mathrm{g})+{ }^{1} / 2 \mathrm{O}_{2} \rightarrow \mathrm{RN}^{+}-\mathrm{O}^{-}
$$

These particular transfers are important in the biophysical chemistry of molybdenum complexes, and the order of decreasing enthalpy of reaction provides a method for predicting the feasibility of such conversions. Limited enthal pies of formation have restricted the scale to a "scarce" selected compounds. The dissociation enthalpy of the $\left(\mathrm{N}^{+}-\mathrm{O}^{-}\right)$dative covalent bond shows large variations depending on the molecular environment in the immediate vicinity of the bond. The present paper reports the mean molar $\left(\mathrm{N}^{+}-\mathrm{O}^{-}\right)$bond dissociation enthalpies, $\langle\mathrm{D}(\mathrm{N}-\mathrm{O})\rangle$, in pyrazine di-N-oxide and in the quinoxaline di- $\mathrm{N}$-oxide derivatives shown in Scheme 1.

The standard molar enthalpies of formation of the compounds 1-7 in the gaseous state were derived from the enthal pies of combustion of the crystalline solids and the enthal pies of sublimation. To derive the mean $\left(\mathrm{N}^{+}-\right.$ $\mathrm{O}^{-}$) bond dissociation enthal pies, the enthalpies of formation of the corresponding quinoxaline derivatives and of pyrazine are required. Unfortunately, quinoxaline derivatives are so difficult to obtain in a sufficiently pure condition for precise combustion measurements that only two experimental values are available: for quinoxaline ${ }^{3}$

† University of North Texas.

₹ Departamento de Química, Universidade do Porto.

$\S$ Instituto de Ciências Biomédicas, Universidade do Porto.

$\perp$ University of Manchester.

$\otimes$ Abstract published in Advance ACS Abstracts, May 15, 1997.

(1) Holm, R. H. Chem. Rev. 1987, 87, 1401.

(2) Caradonna, J . P.; Reddy, P. R.; Holm, R. H. J . Am. Chem. Soc. 1988, 110, 2139.

(3) Ribeiro da Silva, M. A. V.; Matos, M. A. R.; Morais, V. M. F. J . Chem. Soc., Faraday Trans. 1995, 91, 1907.

\section{Scheme 1}<smiles>O=c1ccn(O)c2ccccc12</smiles><smiles>CC(=O)C1=C(C)N(O)c2ccccc2N1[O-]</smiles><smiles>CC(=O)c1c(C)n(O)c2ccccc2[n+]1=O</smiles>

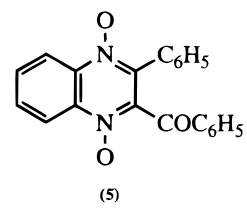<smiles>Cc1cnc(C(=O)O)cn1</smiles><smiles>Oc1ccncc1</smiles>

and for 2,3-dimethylquinoxaline. ${ }^{4}$ The measurement of 2-methyl-5-pyrazinecarboxylic acid was undertaken to facilitate the thermochemical estimation of the required enthalpies of formation of the quinoxaline derivatives.

To assist in the interpretation of the trends in the mean $\left(\mathrm{N}^{+}-\mathrm{O}^{-}\right)$dissociation enthal pies, ab initio calculations were made to investigate the geometric structures of some of these molecules.

\section{Experimental Section}

Materials. Quinoxaline 1,4-dioxide (1) was prepared by (sodium tungstate + hydrogen peroxide) oxidation of quinoxaline as described by Kobayashi et al. ${ }^{5}$ 2-Methylquinoxaline

(4) Ribeiro da Silva, M. A. V.; Morais, V. M. F.; Matos, M. A. R.; Rio, C. M. A.; Piedade, C. M. G. S. Struct. Chem. 1996, 7, 329.

(5) Kobayashi, Y.; Kumadaki, I.; Sato, H.; Sekine, Y.; Hara, T. Chem. Pharm. Bull. 1974, 22, 2097. 
1,4-dioxide (2) was obtained from Maybridge Chemical Ltd. 2-Methyl-3-acetylquinoxaline 1,4-dioxide (3) was prepared by dissolving benzofurazan 1-oxide and pentane-2,4-dione in trimethylamine and stirring the resulting solution for $24 \mathrm{~h}$ at ambient temperature; the yellow precipitate was collected by vacuum filtration. 2-Methyl-3-carbomethoxyquinoxal ine 1,4di oxide (4) and 2-phenyl-3-benzoylquinoxaline 1,4-di oxide (5) were prepared in a similar fashion from benzofurazan 1-oxide plus methyl acetoacetate or dibenzoylmethane. ${ }^{6,7}$ Pyrazine 1,4dioxide (6) was prepared by the (sodium tungstate + hydrogen peroxide) oxidation of pyrazine. 2-M ethyl-5-pyrazinecarboxylic acid (7) was a gift from Agro-Pharmaceutical Division of Nippon Soda Co. (Tokyo, J apan). All seven compounds were further purified by four crystallizations from methanol.

Elemental analyses were in good agreement with expected values. Mass fractions for $1, \mathrm{C}_{8} \mathrm{H}_{6} \mathrm{~N}_{2} \mathrm{O}_{2}$ : found, $\mathrm{C}, 0.5932 ; \mathrm{H}$, 0.0374; N, 0.1722; calculated, C, 0.5926; H, 0.0373; N, 0.1728 . For 2, $\mathrm{C}_{9} \mathrm{H}_{8} \mathrm{~N}_{2} \mathrm{O}_{2}$ : found, $\mathrm{C}, 0.6149 ; \mathrm{H}, 0.0451 ; \mathrm{N}, 0.1593$; calculated, $\mathrm{C}, 0.6136 ; \mathrm{H}, 0.0458 ; \mathrm{N}, 0.1590$. For $\mathbf{3}$, $\mathrm{C}_{11} \mathrm{H}_{10} \mathrm{~N}_{2} \mathrm{O}_{3}$ : found, $\mathrm{C}, 0.6060 ; \mathrm{H}, 0.0468 ; \mathrm{N}, 0.1275$; calculated, C, $0.6055 ; \mathrm{H}, 0.0462 ; \mathrm{N}, 0.1284$. For $4, \mathrm{C}_{11} \mathrm{H}_{10} \mathrm{~N}_{2} \mathrm{O}_{4}$ : found, C, $0.5651 ; \mathrm{H}, 0.0418 ; \mathrm{N}, 0.1202$; cal culated, C, 0.5641; H, 0.0430; $\mathrm{N}, 0.1196$. F or 5, $\mathrm{C}_{21} \mathrm{H}_{14} \mathrm{~N}_{2} \mathrm{O}_{3}$ : found, $\mathrm{C}, 0.7378 ; \mathrm{H}$, 0.0398; N, 0.0833; calculated, C, 0.7368; H, 0.0412; N, 0.0818 . For 6, $\mathrm{C}_{4} \mathrm{H}_{4} \mathrm{~N}_{2} \mathrm{O}_{2}$ : found, C, 0.4290; $\mathrm{H}, 0.0355 ; \mathrm{N}, 0.2506$; calculated, $\mathrm{C}, 0.4286 ; \mathrm{H}, 0.0360 ; \mathrm{N}, 0.2499$. For $7, \mathrm{C}_{6} \mathrm{H}_{6} \mathrm{~N}_{2} \mathrm{O}_{2}$ : found, C, 0.5215; H, 0.0429; N, 0.2031; calculated, C, 0.5217; $\mathrm{H}, 0.0438 ; \mathrm{N}, 0.2028$.

Hexadecane was used as an auxiliary combustion aid for some measurements, and its standard specific energy of combustion, $-\Delta_{\mathrm{c}} \mathrm{u}^{0}$, was measured separately. In the combustion of compounds $\mathbf{3}$ and $\mathbf{6}$, for the hexadecane used, $-\Delta_{c} \mathbf{u}^{0} /$ ] $\mathrm{g}^{-1}=47164.7 \pm 2.7$, where the uncertainty is the standard deviation of the mean, in close agreement with the value of Fraser and Prosen ${ }^{8}$ measured for a sample of $99.96 \mathrm{~mol} \%$ purity, $-\Delta_{c} \mathrm{u}^{0} / \mathrm{J} \mathrm{g}^{-1}=47155.0 \pm 3.8$. For compound 5 , a hexadecane sample from a different source was used, for which $-\Delta_{\mathrm{c}} \mathrm{u}^{0} / \mathrm{J} \mathrm{g}^{-1}=47076.7 \pm 3.3$. The chemical composition of an auxiliary combustion aid should be known approximately, but the specific energy of combustion must be known precisely. The difference of ca. $0.2 \%$ between the two hexadecane samples, due to slight difference in purity, will not produce systematic error.

Combustion Calorimetry. The standard molar enthalpies of combustion, $\Delta_{\mathrm{c}} \mathrm{H}_{\mathrm{m}}^{0}$, of $\mathbf{1}, \mathbf{4}$, and $\mathbf{7}$ were measured using the static-bomb calorimeter in Manchester ${ }^{9}$ whereas the remaining compounds $(\mathbf{2}, \mathbf{3}, \mathbf{5}$, and $\mathbf{6})$ were measured using the static-bomb cal orimeter in Porto. ${ }^{10,11}$ The energy equivalents of the cal orimeters, $\epsilon$ (calor), were determined using the combustion of benzoic acid: in Manchester with the NBS SRM 39i for which under standard bomb conditions $-\Delta_{c} \mathrm{u}^{0} / \mathrm{J} \mathrm{g}^{-1}=$ $26434 \pm 3$, for measurements 1, 7, from 12 calibrations, $\epsilon$ (calor) $=15525.40 \pm 0.47 \mathrm{~J} \mathrm{~K}^{-1}$, but for measurement 4, from 8 calibrations, $\epsilon$ (calor) $=15531.70 \pm 0.68 \mathrm{~J} \mathrm{~K}^{-1}$ for an average mass of water added to the cal orimeter of $2897.0 \mathrm{~g}$ : in Porto with Bureau of Analysed Samples CRM 190p for which $-\Delta_{c} u^{0} / \mathrm{J} \mathrm{g}^{-1}=26431.8 \pm 3.7$, and from 8 calibrations, $\epsilon$ (cal or) $=15911.2 \pm 1.5 \mathrm{~J} \mathrm{~K}^{-1}$ for an average mass of water added to the calorimeter of $3119.6 \mathrm{~g}$. Both calorimeters and experimental techniques were tested for systematic errors by making independent measurements of the energy of combustion of 3-methylcatechol with the results: Manchester, $-\Delta_{c} \mathrm{u}^{0} / \mathrm{J} \mathrm{g}^{-1}$ $=28216.9 \pm 1.9 ;$ Porto, $-\Delta_{c} \mathrm{u}^{0} / \mathrm{J} \mathrm{g}^{-1}=28217.7 \pm 0.9 .^{11}$ The experimental conditions were similar for both calorimeters. Samples were ignited at $298.150 \pm 0.001 \mathrm{~K}$ in oxygen at 3.04

(6) Terrian, D. L.; Houghtaling, M. A.; Ames, J . R. J . Chem. Educ. 1992, 69, 589 .

(7) Issidorides, C. H.; Haddadin, M. J . J . Org. Chem. 1966, 31, 4067. (8) Fraser, F. M.; Prosen, E. J . J . Res. Natl Bur. Stand. 1955, 55, 329.

(9) Bickerton, J .; Pilcher, G.; Al-Takhin, G. J . Chem. Thermodyn. 1984, 16, 373.

(10) Ribeiro da Silva, M. D. M. C.; Ribeiro da Silva, M. A. V.; Pilcher, G. J. Chem. Thermodyn. 1984, 16, 1149.

(11) Ribeiro da Silva, M. A. V.: Ribeiro da Silva, M. D. M. C.: Pilcher, G. Rev. Port. Qu'ım. 1984, 26, 163.
MPa with $1 \mathrm{~cm}^{3}$ of water added to the bomb. The electrical energy of ignition was determined from the change in potential difference across a capacitor when discharged through the platinum ignition wire. For the cotton thread fuse, empirical formula $\mathrm{CH}_{1.686} \mathrm{O}_{0.843},-\Delta_{c} \mathrm{u}^{0}=16250 \mathrm{~J} \mathrm{~g}^{-1} .12$ Corrections for nitric acid formation were based on $-59.7 \mathrm{~kJ} \mathrm{~mol}^{-1}$ for the molar energy of formation of $0.1 \mathrm{~mol} \mathrm{dm}{ }^{-3} \mathrm{HNO}_{3}(\mathrm{aq})$ from $\mathrm{N}_{2}$, $\mathrm{O}_{2}$, and $\mathrm{H}_{2} \mathrm{O}(\mathrm{I}) .{ }^{13}$ Corrections for carbon formation were based on $-\Delta_{\mathrm{c}} \mathrm{u}^{0}=33 \mathrm{~kJ} \mathrm{~g}^{-1} .{ }^{12}$ For each compound, at $298.15 \mathrm{~K}$, (2u/ $\partial \mathrm{p})_{\mathrm{T}}$ was assumed to be $-0.2 \mathrm{~J} \mathrm{~g}^{-1} \mathrm{MPa}^{-1}$, a value typical for most organic solids. For each compound, $-\Delta_{\mathrm{C}} \mathrm{u}^{0}$ was calculated by the procedure given by Hubbard et al. ${ }^{12}$ The relative atomic masses used were those recommended by the IUPAC Commission. ${ }^{14}$ The amount of substance used in each experiment was determined from the total mass of carbon dioxide produced after allowance for that from the cotton thread fuse, hexadecane, and that lost due to carbon formation. The average ratios of the mass of carbon dioxide produced by the samples to that calculated from its mass with uncertainties of twice the standard deviation of the mean value were as follows: $\mathbf{1}$, $0.9995 \pm 0.0001 ; \mathbf{2}, 1.0001 \pm 0.0003 ; \mathbf{3}, 1.0003 \pm 0.0013 ; \mathbf{4}$, $1.0000 \pm 0.0003 ; \mathbf{5}, 0.9980 \pm 0.0003 ; \mathbf{6}, 1.0004 \pm 0.0004 ; \mathbf{7}$, $0.9995 \pm 0.0003$

Enthalpies of Sublimation. The enthalpies of sublimation of $\mathbf{1}, \mathbf{2}, \mathbf{4}, \mathbf{6}$, and $\mathbf{7}$ were measured using the "vacuumsublimation" drop microcal orimetric method. ${ }^{15}$ Samples, about $5 \mathrm{mg}$, of each compound, contained in a thin glass capillary tube sealed at one end were dropped at room temperature into the hot reaction vessel in the Calvet High Temperature Microcal orimeter (SETARAM HT1000) and then removed from the hot zone by vacuum sublimation. The observed enthal pies of sublimation $\left[\mathrm{H}_{\mathrm{m}}^{0}(\mathrm{~g}, \mathrm{~T} \mathrm{~K})-\mathrm{H}_{\mathrm{m}}^{0}(\mathrm{cr}, 298.15 \mathrm{~K})\right]$, were corrected to $298.15 \mathrm{~K}$ using $\Delta_{298.15 \mathrm{~K}}^{\mathrm{TK}} \mathrm{H}_{\mathrm{m}}^{\mathrm{O}}(\mathrm{g})$ estimated by a group method based on the values of Stull et al. ${ }^{16}$ The microcalorimeter was calibrated in situ for these measurements using the reported enthalpy of sublimation of naphthalene. ${ }^{17}$

F or compounds $\mathbf{3}$ and 5, the Knudsen effusion method as described by Burkinshaw and M ortimer ${ }^{18}$ was used. The vapor effusing from a Knudsen cell was allowed to condense on a quartz crystal positioned above the effusion hole, and changes in frequency of oscillation of the quartz plate were proportional to the mass condensed. From the Knudsen formula,

$$
\mathrm{p}=\frac{\mathrm{m}}{\mathrm{a}}\left(\frac{2 \pi \mathrm{RT}}{\mathrm{M}}\right)^{1 / 2}
$$

where $\mathrm{m}$ is the rate of mass loss, a the effective hole area, and $M$ the molar mass of the effusing vapor, as the rate of change in frequency $v$ is proportional to the rate of mass loss, then

$$
\ln p=\ln \left(v T^{1 / 2}\right)+\ln \left(\frac{2 \pi R}{a^{2} M}\right)^{1 / 2}
$$

and hence the standard molar enthalpy of sublimation, $\Delta_{\mathrm{cr}}^{\mathrm{g}} \mathrm{H}_{\mathrm{m}}^{0}$, can be derived from the sl ope of $\operatorname{In}\left(\mathrm{vT}^{1 / 2}\right)$ versus $\mathrm{T}^{-1}$ by applying the integrated form of Clausius-Clapeyron equation. The measurements were made in Porto using an Edwards 306 vacuum coating unit providing a minimum pressure of $7 \times$ $10^{-5} \mathrm{~Pa}$, fitted with an FTM3 film thickness monitor incorporating a quartz crystal oscillator $(6 \mathrm{MHz})$ but with some modifications from the apparatus described by Burkinshaw and Mortimer. ${ }^{18}$ The cylindrical Knudsen cell was made of

(12) Hubbard, W. N.; Scott, D. W.; Waddington, G. In Experimental Thermochemistry; Rossini, F. D.; Ed.; Interscience: New York, 1956.

(13) The NBS Tables of Chemical Thermodynamic Properties. J . Phys. Chem. Ref. Data 1982, 11.

(14) IUPAC. J . Phys. Chem. Ref. Data 1993, 22, 1571.

(15) Adedeji, F. A.; Brown, D. L. S.; Connor, J . A.; Leung, M.; PazAndrade, M. I.; Skinner, H. A. J . Organomet. Chem. 1975, 97, 221.

(16) Stull, D. R.; Westrum, E. F.; Sinke, G. C. The Chemical Thermodynamics of Organic Compounds; Wiley: New York, 1969.

(17) de Kruif, C. G.; Kuipers, T.; van Mittenburg, J . C.; Schaake, R. C. F.; Stevens, G. J . Chem. Thermodyn. 1981, 13, 1081.

(18) Burkinshaw, P. M.; Mortimer, C. T. J . Chem. Soc., Dalton Trans. 1984, 75. 
Table 1. Typical Combustion Measurements at $\mathrm{T}=298.15 \mathrm{~K}\left(\mathrm{p}^{0}=0.1 \mathrm{MPa}\right)$

\begin{tabular}{|c|c|c|c|c|c|c|c|}
\hline & 1 & 2 & 3 & 4 & 5 & 6 & 7 \\
\hline $\mathrm{m}\left(\mathrm{CO}_{2}\right.$, total $) / \mathrm{g}$ & 1.73197 & 1.69077 & 1.39041 & 2.08642 & 1.92553 & 1.50739 & 1.94323 \\
\hline $\mathrm{m}(\mathrm{cpd}) / \mathrm{g}$ & 0.79509 & 0.74963 & 0.37903 & 1.00740 & 0.43525 & 0.50788 & 1.01423 \\
\hline $\mathrm{m}$ (hexadecane)/g & & & 0.17469 & & 0.23931 & 0.22536 & \\
\hline $\mathrm{m}($ fuse $) / \mathrm{g}$ & 0.00343 & 0.00334 & 0.00389 & 0.00257 & 0.00394 & 0.00554 & 0.00288 \\
\hline$\Delta \mathrm{T}_{\mathrm{ad}} / \mathrm{K}$ & 1.30972 & 1.27713 & 1.14196 & 1.52885 & 1.54790 & 1.30839 & 1.38235 \\
\hline$\epsilon($ calor $) / J \mathrm{~K}^{-1}$ & 15525.4 & 15911.2 & 15911.2 & 15531.7 & 15911.2 & 15911.2 & 15525.4 \\
\hline$\left.\epsilon_{\mathrm{f}} /\right] \mathrm{K}^{-1}$ & 12.89 & 15.32 & 16.05 & 13.41 & 16.15 & 15.89 & 13.36 \\
\hline$\Delta \mathrm{m}\left(\mathrm{H}_{2} \mathrm{O}\right) / \mathrm{g}$ & 0.0 & 0.1 & -0.1 & -2.6 & -0.1 & -0.1 & 0.0 \\
\hline$-\Delta \mathrm{U}(\mathrm{IBP}) / \mathrm{J}$ & 20349.7 & 20339.7 & 18186.8 & 23748.4 & 24652.2 & 20837.7 & 21478.9 \\
\hline$\left.\Delta \mathrm{U}\left(\mathrm{HNO}_{3}\right) /\right]$ & 66.9 & 62.0 & 30.6 & 72.7 & 27.5 & 60.8 & 82.0 \\
\hline$\Delta \mathrm{U}($ carbon $) /]$ & 0.0 & 0.0 & 0.0 & 0.0 & 0.0 & 0.0 & 3.30 \\
\hline$\Delta U$ (ignition)/J & 1.1 & 1.0 & 1.0 & 1.1 & 1.1 & 0.6 & 1.1 \\
\hline$\Delta U_{\Sigma / J}$ & 13.2 & 15.2 & 9.4 & 16.9 & 12.6 & 12.3 & 14.5 \\
\hline$-m \Delta_{c} u^{0}($ hexadecane)/J & & & 8239.2 & & 11265.8 & 10629.0 & \\
\hline$-m \Delta_{c} u^{0}($ fuse $) / J$ & 55.8 & 54.2 & 63.2 & 41.7 & 64.0 & 90.0 & 46.8 \\
\hline$\left.-\Delta_{c} \mathrm{u}^{0}(\mathrm{cpd}) /\right] \mathrm{g}^{-1}$ & 25423.3 & 26957.6 & 25972.6 & 23443.6 & 30516.5 & 19779.5 & 21039.5 \\
\hline
\end{tabular}

Table 2. Values of $-\Delta_{c} \mathbf{u}^{0} / \mathrm{J} \mathrm{g}^{-1}$ at $298.15 \mathrm{~K}$

\begin{tabular}{ccccccc}
\hline $\mathbf{1}$ & $\mathbf{2}$ & $\mathbf{3}$ & $\mathbf{4}$ & $\mathbf{5}$ & $\mathbf{6}$ & $\mathbf{7}$ \\
\hline 25423.3 & 26933.0 & 26000.4 & 23443.6 & 30505.2 & 19762.8 & 21039.5 \\
25424.2 & 26964.3 & 26022.6 & 23448.2 & 30516.3 & 19811.7 & 21035.2 \\
25423.3 & 26933.0 & 26027.6 & 23454.7 & 30509.2 & 19786.0 & 21032.0 \\
25425.1 & 26924.5 & 25956.1 & 23444.9 & 30545.9 & 19786.8 & 21033.6 \\
25420.1 & 26957.6 & 26003.5 & 23453.7 & 30535.9 & 19809.0 & 21035.5 \\
25411.9 & 26982.6 & 26027.2 & 23448.0 & 30528.5 & 19769.2 & 21028.5 \\
& & 26004.4 & & & & 19779.5
\end{tabular}

\begin{tabular}{|c|c|c|c|c|c|c|}
\hline & & & $-\left\langle\Delta_{c} u^{0}\right\rangle / J g^{-1}$ & & & \\
\hline $25421.3 \pm 2.0$ & $26949.2 \pm 9.2$ & $26001.8 \pm 9.1$ & $23448.9 \pm 1.8$ & $30523.5 \pm 6.5$ & $19786.4 \pm 7.0$ & \\
\hline
\end{tabular}

Table 3. Derived Molar Values $\left(\mathrm{kJ} \mathrm{mol}^{-1}\right)$ at $\mathbf{T}=298.15 \mathrm{~K}$

\begin{tabular}{rrrrrr}
\hline & \multicolumn{1}{c}{$-\Delta_{\mathrm{c}} \mathrm{U}_{\mathrm{m}}^{0}(\mathrm{cr})$} & \multicolumn{1}{c}{$-\Delta_{\mathrm{c}} \mathrm{U}_{\mathrm{m}}^{0}(\mathrm{cr})$} & \multicolumn{1}{c}{$\Delta_{\mathrm{f}} \mathrm{U}_{\mathrm{m}}^{0}(\mathrm{cr})$} & \multicolumn{1}{c}{$\Delta_{\mathrm{cr}}^{\mathrm{g}} \mathrm{U}_{\mathrm{m}}^{0}$} & \multicolumn{1}{c}{$\Delta_{\mathrm{f}} \mathrm{U}_{\mathrm{m}}^{0}(\mathrm{~g})$} \\
\hline $\mathbf{1}$ & $4122.0 \pm 0.9$ & $4120.7 \pm 0.9$ & $115.1 \pm 1.4$ & $112.0 \pm 1.9$ & $227.1 \pm 2.4$ \\
$\mathbf{2}$ & $4747.8 \pm 3.4$ & $4747.8 \pm 3.4$ & $62.9 \pm 3.6$ & $107.0 \pm 6.2$ & $169.9 \pm 7.2$ \\
$\mathbf{3}$ & $5673.9 \pm 4.2$ & $5673.9 \pm 4.2$ & $-83.9 \pm 4.4$ & $117.0 \pm 2.4$ & $33.1 \pm 5.0$ \\
$\mathbf{4}$ & $5492.0 \pm 1.2$ & $5490.8 \pm 1.2$ & $-267.0 \pm 1.9$ & $118.3 \pm 2.6$ & $-148.7 \pm 3.2$ \\
$\mathbf{5}$ & $10449.8 \pm 5.2$ & $10452.3 \pm 5.2$ & $187.8 \pm 5.9$ & $167.4 \pm 4.0$ & $355.2 \pm 7.1$ \\
$\mathbf{6}$ & $2217.8 \pm 1.6$ & $2215.3 \pm 1.6$ & $69.6 \pm 1.7$ & $116.9 \pm 0.8$ & $186.5 \pm 1.9$ \\
$\mathbf{7}$ & $2905.3 \pm 0.5$ & $2904.1 \pm 0.5$ & $-314.5 \pm 0.9$ & $100.9 \pm 1.5$ & $-213.6 \pm 1.7$
\end{tabular}

steel, external diameter $13 \mathrm{~mm}$, internal diameter $6 \mathrm{~mm}$, and depth $8 \mathrm{~mm}$. The lid with an effusion hole diameter of 0.8 $\mathrm{mm}$ was screwed on to the cell. The complete cell was screwed into an electrically heated cylindrical steel block, and the temperature was controlled to $\pm 0.1 \mathrm{~K}$ by a Eurotherm 815 proportional integral derivative controller. Temperatures were measured by a Labfacility P100/0620 platinum sensing detector screwed into the effusion cell. Frequency changes in the quartz crystal oscillator circuit were measured with a Philips Frequency Counter PM6685 connected to the FTM3 thickness monitor. The equipment was tested with several compounds of known standard molar enthalpy of sublimation.

\section{Results}

Results for a typical combustion experiment on each compound are given in Table $1 ; \Delta \mathrm{m}\left(\mathrm{H}_{2} \mathrm{O}\right)$ is the deviation of the mass of water added to the calorimeter from the average mass assigned to $\epsilon$ (calor). Samples were ignited at $298.15 \mathrm{~K}$ so that $\Delta \mathrm{U}(\mathrm{IBP})=-\left\{\epsilon\right.$ (calor) $+\mathrm{C}_{\mathrm{p}}\left(\mathrm{H}_{2} \mathrm{O}\right.$, I) $\left.\Delta \mathrm{m}\left(\mathrm{H}_{2} \mathrm{O}\right)+\epsilon_{\mathrm{f}}\right\} \Delta \mathrm{T}_{\mathrm{ad}}+\Delta \mathrm{U}$ (ign); $\Delta \mathrm{U}_{\Sigma}$ is the correction to the standard state, and the remaining terms are as previously defined. ${ }^{12}$ The individual values of $\Delta_{c} u^{0}$ with the mean and its standard deviation are given in Table 2. Table 3 lists the derived standard molar enthal pies of combustion, $\Delta_{c} \mathrm{H}_{\mathrm{m}}^{0}$, and formation, $\Delta_{\mathrm{f}} \mathrm{H}_{\mathrm{m}}^{0}$, in the crystalline and gaseous states. In accordance with normal thermochemical practice, the uncertainties assigned to the derived molar enthalpies are twice the overall standard deviations of the mean and include the uncer- tainties in calibration and in the values of the auxiliary quantities used. To derive $\Delta_{\mathrm{f}} \mathrm{H}_{\mathrm{m}}^{0}$ from $\Delta_{\mathrm{c}} \mathrm{H}_{\mathrm{m}}^{0}$, the values $\Delta_{\mathrm{f}} \mathrm{H}_{\mathrm{m}}^{0}\left(\mathrm{H}_{2} \mathrm{O}, \mathrm{I}\right) / \mathrm{kJ} \mathrm{mol}^{-1}=-285.83 \pm 0.04$ and $\Delta_{\mathrm{f}} \mathrm{H}_{\mathrm{m}}^{0}\left(\mathrm{CO}_{2}, \mathrm{~g}\right) / \mathrm{kJ} \mathrm{mol}{ }^{-1}=-393.51 \pm 0.13^{19}$ were used.

\section{Discussion}

The mean $\left(\mathrm{N}^{+}-\mathrm{O}^{-}\right)$bond dissociation enthal py is onehalf of the enthalpy of the gaseous reaction

$$
\mathrm{O}^{-}-\stackrel{+}{\mathrm{N}}-\mathrm{R}-\stackrel{+}{\mathrm{N}}-\mathrm{O}^{-} \rightarrow \mathrm{N}-\mathrm{R}-\mathrm{N}+2 \mathrm{O}
$$

requiring $\Delta_{\mathrm{f}} \mathrm{H}_{\mathrm{m}}^{0}(\mathrm{O}, \mathrm{g}) / \mathrm{kJ} \mathrm{mol}^{-1}=249.18 \pm 0.10^{19}$ and $\Delta_{\mathrm{f}} \mathrm{H}_{\mathrm{m}}^{0}(\mathrm{~g})$ for $\mathrm{N}-\mathrm{R}-\mathrm{N}$ : the only experimental values for the latter are for quinoxaline, ${ }^{3}$ 2,3-dimethylquinoxaline ${ }^{4}$ and pyrazine; ${ }^{20}$ the remaining required values may be estimated using group additivity methods. It appears that the increment in $\Delta_{\mathrm{f}} \mathrm{H}_{\mathrm{m}}^{0}(\mathrm{~g})$ for substitution into the pyrazine ring is the same as for benzene: eg., for 2-methyl-5-pyrazinecarboxilic acid an estimate using $\Delta_{\mathrm{f}} \mathrm{H}_{\mathrm{m}}^{0}(\mathrm{~g})$ values for (pyrazine + toluene + benzoic acid 2 benzene) gives $-212.8 \pm 3.0 \mathrm{~kJ} \mathrm{~mol}^{-1}$ agreeing with the experimental value of $-213.6 \pm 1.7 \mathrm{~kJ} \mathrm{~mol}^{-1}$, and for 2,3-dimethylquinoxaline, an estimate by (quinoxaline +

(19) Cox, J . D.; Wagman, D. D.; Medvedev, V. A. CODATA Key Values for Thermodynamics; Hemisphere: New York, 1989.

(20) Tjebbes, J . Acta Chem. Scand. 1962, 16, 916. 
Table 4. Mean Bond Dissociation Enthalpies

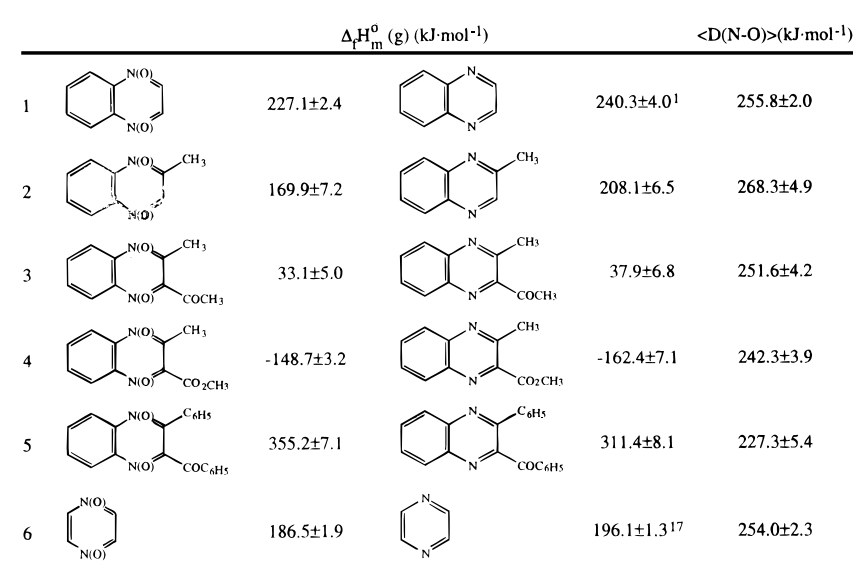

2 toluene -2 benzene) gives $-175.9 \pm 4.4 \mathrm{~kJ} \mathrm{~mol}^{-1}$ in agreement with the experimental value $172.9 \pm 3.0 \mathrm{~kJ}$ $\mathrm{mol}^{-1} .4$ Using the following $\Delta_{\mathrm{f}} \mathrm{H}_{\mathrm{m}}^{0}(\mathrm{~g}) / \mathrm{kJ} \mathrm{mol} \mathrm{malues}^{-1}{ }^{21}$ $\mathrm{C}_{6} \mathrm{H}_{6}, 82.6 \pm 0.7 ; \mathrm{C}_{6} \mathrm{H}_{5} \mathrm{CH}_{3}, 50.4 \pm 0.6 ; \mathrm{C}_{6} \mathrm{H}_{5} \mathrm{COCH}_{3}$, $-86.7 \pm 1.6 ; \mathrm{C}_{6} \mathrm{H}_{5} \mathrm{CO}_{2} \mathrm{CH}_{3},-287.9 \pm 2.4 ; \mathrm{C}_{6} \mathrm{H}_{5} \mathrm{C}_{6} \mathrm{H}_{5}, 181.4$ \pm 2.0; $\mathrm{C}_{6} \mathrm{H}_{5} \mathrm{COC}_{6} \mathrm{H}_{5}, 54.9 \pm 4.4$, the estimated $\Delta_{\mathrm{f}} \mathrm{H}_{\mathrm{m}}^{0}(\mathrm{~g}) / \mathrm{kJ} \mathrm{mol}^{-1}$ values for the quinoxaline derivatives given in Table 4 were derived using this assumption with an additional uncertainty of $\pm 5.0 \mathrm{~kJ} \mathrm{~mol}{ }^{-1}$ but with no allowance made for possible steric strain. Table 4 shows that $\langle\mathrm{D}(\mathrm{N}-\mathrm{O})\rangle$ in quinoxaline di-N-oxide and in pyrazine di-N-oxide are the same but there is a reduction for compounds $\mathbf{4}$ and $\mathbf{5}$ which may be partially due to the neglect of possible steric hindrance in the estimation of $\Delta_{\mathrm{f}} \mathrm{H}_{\mathrm{m}}^{0}(\mathrm{~g})$ for the quinoxaline derivatives. These compounds can be ordered using the reaction scheme of $\mathrm{Holm}$ et al.,1,2 in terms of their abilities to transfer oxygen atoms in the $\mathrm{Mo}(\mathrm{IV})$ to $\mathrm{Mo}(\mathrm{VI})$ conversion by considering one-half of the enthalpy of the gaseous reaction,

quinoxaline derivative $+\mathrm{O}_{2} \rightarrow$ quinoxaline di-N-oxide derivative

giving: $\mathbf{5}\left(21.9 \pm 5.4 \mathrm{~kJ} \mathrm{~mol}{ }^{-1}\right) ; \mathbf{4}\left(6.9 \pm 3.9 \mathrm{~kJ} \mathrm{~mol}{ }^{-1}\right) ; \mathbf{3}$ $\left(-2.4 \pm 4.2 \mathrm{~kJ} \mathrm{~mol}^{-1}\right) ; \mathbf{6}\left(-4.8 \pm 1.2 \mathrm{~kJ} \mathrm{~mol}^{-1}\right) ; \mathbf{1}(-6.6 \pm$ $\left.2.4 \mathrm{~kJ} \mathrm{~mol}^{-1}\right) ; 2\left(-19.1 \pm 4.9 \mathrm{~kJ} \mathrm{~mol}^{-1}\right)$. As expected, the more highly strained $\mathrm{N}$-oxide derivatives are the more powerful oxidizing agents. If such strain exists, then the strain in the corresponding di-N-oxides will be greater; hence, some of these structures were investigated by ab initio calculations.

\section{Ab Initio Calculations}

Unconstrained geometry optimizations were performed for the five molecules shown in Scheme 2. All calculations were carried out at the ab initio restricted HartreeFock level using STO-3G minimal basis sets and the American version of the program GAMESS. 22,23 More rigorous calculations are at present precluded by the large number of atoms in these molecules. The resulting optimized geometries of $\mathbf{1}, \mathbf{4}$, and $\mathbf{7}$ were confirmed as true minima through calculation and diagonalization of the respective Hessian matrices, at the same level of ab

(21) Pedley, J . B. Thermochemical Data and Structures of Organic Compounds, vol. I; Thermodynamics Research Center: College Station, Texas, 1994.

(22) Dupuis, M.; Spangler, D.; Wendoloski, J . J . NRCC Software Catalog 1980, 1, Program QG10.

(23) Schmidt, M. W.; Boatz, J. A.; Baldridge, K. K.; Koseki, S.; Gordon, M. S.; Elbert, S. T.; Lam, B. QCPE BulI. 1987, 7, 115.

\section{Scheme 2}<smiles>ON1C=CN(O)C2=C1CCCC2</smiles><smiles></smiles>

9<smiles>OC(=Nc1nc2c(nc1C1CCCCC1)CCCC2)C1CCCCC1</smiles>

initio theory, leading at the same time to the harmonic vibrational frequencies. Similar calculations for $\mathbf{5}$ and $\mathbf{9}$ would be very time consuming because of the large number of degrees of freedom involved and were not made, but we believe the optimized geometries for these molecules are also true minima. The quinoxaline moiety of all these molecules was found to be planar, and the global loss of planarity of 4, 5, 8, and 9 results from the spatial orientation of the substituents with respect to the quinoxaline planar substructure.

In 4 the methyl substituent, which is expected to rotate easily, assumes an orientation so that two of its $\mathrm{H}$ atoms are located almost symmetrically with respect to the quinoxaline plane while the third, $\mathrm{H}_{\mathrm{m}}$, atom is oriented so that its distance from $\mathrm{O}_{2}$ is as large as possible, the $\mathrm{N}_{\mathrm{j}}-\mathrm{C}_{\mathrm{k}}-\mathrm{C}_{\mathrm{l}}-\mathrm{H}_{\mathrm{m}}$ dihedral angle being $173^{\circ}$. For 8 the methyl substituent assumes a symmetrical orientation relative to the quinoxaline plane but the in-plane $\mathrm{H}$ atom is oriented so that its distance from $\mathrm{N}_{\mathrm{j}}$ is minimum, $\mathrm{N}_{\mathrm{j}}$ $\mathrm{C}_{\mathrm{k}}-\mathrm{C}_{1}-\mathrm{H}_{\mathrm{m}}$ dihedral angle being now $-3^{\circ}$. The other substituent in $\mathbf{4}$ shows similar behavior rotating so that the $\mathrm{O}_{\mathrm{d}}$ atom lies far from the $\mathrm{O}_{1}$ atom of the quinoxaline di-N-oxide. The $\mathrm{N}_{\mathrm{a}}-\mathrm{C}_{\mathrm{b}}-\mathrm{C}_{\mathrm{c}}-\mathrm{O}_{\mathrm{d}}$ dihedral angle is $-129^{\circ}$ whereas for 8 this angle assumes a value of $-164^{\circ}$ indicating that the $\mathrm{C}_{b}-\mathrm{C}_{c}-\mathrm{O}_{d}-\mathrm{O}_{e}$ group is closer to planarity with the quinoxaline plane: complete planarity would correspond to a dihedral angle of $-180^{\circ}$.

These conformations of the two molecules suggest the occurrence of steric hindrance and that due to the presence of the $\mathrm{O}$ atoms in the di-N-oxide is greatly attenuated in the molecule with the $\mathrm{O}$ atoms removed. Steric hindrance can destabilize 4 with respect to $\mathbf{8}$, and since this destabilization does not occur in the nonsubstituted quinoxaline derivatives, this would account for a decrease in $\langle\mathrm{D}(\mathrm{N}-\mathrm{O})\rangle$ in $\mathbf{4}$ relative to $\mathbf{1}$.

The results of the geometry optimization of $\mathbf{5}$ and $\mathbf{9}$ suggest a similar behavior. In both cases the substituent benzene rings are not coplanar with the quinoxaline moiety. The dihedral angle $\mathrm{N}_{a}-\mathrm{C}_{b}-\mathrm{C}_{c}-\mathrm{O}_{\mathrm{d}}$ is $-106^{\circ}$ for 5 and $-125^{\circ}$ for 9 while the dihedral angle $\mathrm{N}_{e}-\mathrm{C}_{\mathrm{f}}-\mathrm{C}_{\mathrm{g}}-$ $C_{i}$ assumes values of $-124^{\circ}$ and $-137^{\circ}$ respectively for 5 
and $\mathbf{9}$. The two substituents assume more planar conformations, with respect to the quinoxal ine moiety plane, when the $\mathrm{O}$ atoms are removed which is compati ble with increased steric hindrance due to the presence of the $\mathrm{O}$ atoms in the di- $\mathrm{N}$-oxide molecules.

The fact that these molecules become more planar upon breaking of the $\mathrm{N}-\mathrm{O}$ bonds may have other consequences. If the molecules were completely planar the extended delocalization could occur between the $\mathrm{C}_{c}-\mathrm{O}_{d}$ double bonds and the quinoxaline ring and between the benzene rings of the substituents and the quinoxaline rings.

Natural bond orbital (NBO) analysi ${ }^{24,25}$ has been performed for each compound. NBO analysis provides a description of bonding structure in terms of highly occupied local ized single and double bonds and lone pairs which are compatible with the electronic density resulting from the Hartree-Fock wave function. This description corresponds closely to the classical Lewis picture of chemical bonding. In systems showing electronic delocalization no single localized description can account for all the Hartree-Fock electronic density, and so a convenient measure of delocalization is the fraction of the total electronic density not described by the localized structures; we found that the non-Lewis electronic density amounts to $2.4 \%, 2.7 \%, 2.0 \%, 2.3 \%, 2.7 \%$, and $2.8 \%$ of the total electronic density, for compounds quinoxaline, $\mathbf{1}, \mathbf{8}, \mathbf{4}, \mathbf{9}$, and $\mathbf{5}$, respectively. These fractions will appear as small populations of the corresponding antibonding orbitals which are formally unoccupied when delocalization does not occur. Thus, for compounds $\mathbf{8}$ and $\mathbf{4}$ the antibonding $\pi_{c_{c}-O_{d}}$ bond orbitals show populations of 0.18 and 0.16 electrons, respectively, whereas for compounds 9 and 5 the occupations of the same antibonding orbitals are 0.09 and 0.08 electrons, respectively. The occurrence of such bonding-antibonding stabilizing interactions implies that any attempt to describe the bonding structure through localized bonds and lone pairs will not be

(24) Foster, J . P.; Weinhold, F. J . Am. Chem. Soc. 1980, 102, 7211.

(25) Reed, A. E.; Weinhold, F. J . Chem. Phys. 1983, 78, 4066. completely reliable. The natural localized molecular orbitals (NLMO) describing the $\pi_{\mathrm{N}_{\mathrm{a}}-\mathrm{C}_{\mathrm{b}}}$ bond has nonnegligible contributions from the $\mathrm{p}_{\pi}$ atomic orbital of atom $\mathrm{C}_{\mathrm{c}}$ of $1.2 \%, 0.7 \%, 0.6 \%$, and $0.3 \%$ respectively for $\mathbf{8 , 4}, \mathbf{9}$, and $\mathbf{5}$, while the contribution of the $\mathrm{p}_{\pi}$ atomic orbital of atom $\mathrm{O}_{\mathrm{d}}$ assumes values of $0.2 \%, 0.1 \%, 1.2 \%$, and $1.1 \%$ for the same molecules. On the other hand, the NLMO describing the $\pi_{\mathrm{N}_{\mathrm{e}}-\mathrm{C}_{\mathrm{f}}}$ bond shows contributions from the $\mathrm{p}_{\pi}$ atomic orbital of atom $\mathrm{C}_{g}$ of $0.2 \%$ and $0.1 \%$ for 9 and 5, respectively: for the $C_{i} p_{\pi}$ atomic orbital these contributions are $0.3 \%$ and $0.2 \%$ for 9 and 5, respectively.

These delocalization effects can thus be depicted as a charge transfer from the highly occupied bond orbitals into adjacent unoccupied antibonding orbitals and their importance can be more quantitatively characterized through a second-order perturbative treatment of the Fock matrix in the NBO basis, which gives the energy lowering associated with such interactions. By this type of calculation we found that the "donor-acceptor" interactions which represent the main contributions to the stabilization of $\mathbf{4}$ and $\mathbf{8}$ occur between the $\pi_{\mathrm{N}_{\mathrm{a}}-\mathrm{C}_{\mathrm{b}}}$ bond orbital with the antibonding $\pi \epsilon_{c}^{*}-O_{d}$ bond orbital and are associated with energy lowerings of 32.6 and $84.1 \mathrm{~kJ}$ $\mathrm{mol}^{-1}$, respectively. Similarly, the same nominal interactions for $\mathbf{5}$ and $\mathbf{9}$ produce energy lowerings of 5.0 and 32.2 kJ $\mathrm{mol}^{-1}$, respectively. For $\mathbf{5}$ and $\mathbf{9}$, we found that another important interaction occurs between the bonding $\pi_{\mathrm{N}_{\mathrm{e}}-\mathrm{C}_{\mathrm{f}}}$ bond orbital with the $\pi_{\mathrm{c}_{\mathrm{i}}-\mathrm{C}_{\mathrm{g}}}$ bond orbital is associated with energy lowerings of 11.3 and $25.9 \mathrm{~kJ}$ $\mathrm{mol}^{-1}$, respectively. These different stabilization energies through extended delocalizations can be ascribed to the different conformations and are in qual itative accord with the differences in the $\langle\mathrm{D}(\mathrm{N}-\mathrm{O})\rangle$ values.

Acknowledgment. Authors from Porto University thank Centro de Investigação em Química (Unidade de I\&D no. 81/94, J NICT) for financial support. Thanks are also due to Cláudia M. V. Vaz for some measurements on compound 6 .

J O962149S 